\title{
A Brief Critical Revision of the Fusulina=Species Recently Described, with Additional Studies on Japanese Fusulinae.
}

BY

\author{
Yoshiaki Ozawa.
}

With 2 Plates.

Recently a number of papers on Fusulinae have been publisbed, by Yabe, Hayasaka, Lee, Colani and me. The titles ${ }^{17}$ of these papers by the other authors are given in the footnotes. below. I will here briefly review the species described by them.

Prof. Yabe and Assist. Prof. Hayasaka of the Tohoku imperial University figured and named the following species of Fusulina from China, but so far as I am aware, not described.

Fusulinella deprati n. sp.

Fusulinella sphaerica n. sp.

Fusulina sino-indica n. sp.

Schwagerina princeps (Ehrenb.)

Schwagerina (Verbeekina) verbeelki (Geinita)

Doliotina lepida Schwager

Doliolina gigantea n. sp.

of these, Doliolina gigantea would seem from the illustrations.

1) Tabe and Hayasaka: Atlas of Fossils in Geographical Researsh of China. Pl. XVII and Pl. XXI. 1920.

J. S. Lee: A graphic Method to aid specific Determination of Fusulinoids and some Results of its Application to the Fusulinas from North Chine. Bull. Geol. Soc. China, Vol. II., No. 3-4. pp. 51-\$6.

I. Hayasaka: On the Fauna of the Anthracolithic Limesthne of Omi-muira in the western Tart of Eohigo. Sci. Rep. Tohokn Imp. Univ. Il Series (Ceol) Vol. VIIL., No. I. 1924.

Colani: Nouvelle Contribution à l'Étude des Fusulinidés de l'Extréme-Orient. Mém. Serv. Géol. d'Tndochine, Vol. XI, fas. 1. 
given to be Verbeekina verbeeki, and the name of Fusulinella sphaerica ${ }^{1)}$ is preoccupied by Abich.

The following is the revised list.

Staffella deprati Yabe

Staffella n. sp.

Fusulina (Schelluvienia) sino-indica Yabe

Fusulina (Schwagerina) princeps (Ehrenb.)

Verbeekina verbeeki (Geinitz)

Doliolina lepida (Schwager)

In 1924 J. S. Lee described and figured the following species from North Ching.

Iusulina vulgaris Schellwien

Fusulina tenuissima Schellw.

Fusulina longissima n. var. arca

Fusulina californica (var. Staff)

Fusulina elongata (=extensa) n. var. minoris

Fusulina verneuili ef. var. sapperi Staff

Fusulina pusilla Schellw.

Fusulina variata a. sp.

The central chamber of the type specimen of Fusulina vulgaris Schellwien is large $(0.25-0.4 \mathrm{~mm})$, whereas in the forms described by Lee its average diameter measures at $0.09 \mathrm{~mm}$. Though Lue's figures are not very clear, the only one which appears to show the central chamber being cut through almost the center. The fact.droots the correctness of his measurement. Then it is possible that Lee's specimens may represent the microsphaeric form of Schellwienia vulgaris. Yet I identified Lee's specimens with my new species Schellwienia satoi ${ }^{2}$ which is described in my recent paper titled "Paleontological Studies on the Limestone of Nagato".

1) V. v. Mollex: Die spiral-gewundenen Foraminiferen des xusisohen Kohleakalks. p. 114.

2) Joux. Coll. Sei. Imp. Univ. Tukyo, Vol. XLV., art. 6. 1925. 
The third species in the above list, Fusulina longissima n. var. arca judging from his figures, is characterized by the wellmarked folding of septa, and it is more nearly related to Fusulina tenuissima than Frusulina longissima.

The revised list is

Fusulina satoi Ozawa

Fusulina tenuissima Schellwien

(=Fusulina longissima n. var. arca)

Fusulina californica Staff

Fusulina elongata Shumard em. Girty var. minoris

Fusulina vernewili ef. var. sapperi Staff

Frusulina pusilla Schellwien

Fusulina variata Lee.

Quite Recently Assist. Prof. Hayasaka of the Tohoku Imperial University published one of the most important contributions to the study of the Paleozoic system in Japan. In this work, the author described the following species of Fusulina obtained from the upper part of the anthracolithic limestone of Omi-mura ${ }^{1)}$.

Neofusulinella biconica n. sp.

Fusulina brevicula Schwager

Fusulina cfr. japonica Gümbel

Doliolina lepida (Schwager)

Schwagerina (Verbeekina) deprati Yabe

Neoschwagerina craticulifera (Schwager).

Of these, Fusulina brevicula, judging from the flgures given by Hayasaka, contains at least two types. The one ${ }^{2}$ is represented by Plate II, figures 9, IO, 12 and Plate III, figure 2 and

1) In the paper "Notes on the Fusulina limestone of Omi-mura" (Jour. Geol. Soc. Tokyo, Vol. XXXII., No. 376, p. 27. -in Japanese- 1925), I bave not only cxitically revised the Fusulina fossils described by Hayasaka, but also listed several Upper Permian fossils such as Sumat ina annoe, Neoschwagerina douvillei, Yabeina hoyasaskcai ( $Y$. multiseptato), Mizzia velebitana and Lonsdateia (Waagenophy(um) timorica Gerth, etc.

2) This species will be described in the following pages of this paper under the name Fusulina prisca var. parvula. 
evidently belongs to the group of Fusulina prisca or Fusulina. centralis and the other, becanse of the insufficient illustrations, is. undeterminable. Schwagerina deprati Yabe, so far as I am aware, has been neither described nor illustrated by Yabe. This species. is undoubtedly Verbeekina verbeeki. The illustrations of Neoschwagerina craticulifera (P1. III., figs. 9, 10) given by Hayasaka. show the characteristic peculiarities of Neoschwagerina globosa, and moreover one of them has a large initial chamber. Therefore they are none but Neoschwagerina multiseptata. ${ }^{1)}$

The revised list is as follows.

Fusulinella biconica (Hayasaka)

Fusulina prisca var. parvula Schellwien

Fusulina cfr. douvillei Colani

Doliolina lepida Schwager

Verbeekina verbeeki (Geinita)

Neoschwagerina (Yabeina) multiseptata (Deprat)

Miss M. Colani's paper on the study of Fusulinae is very voluminous aud well illustrated. It contains several new species, of which Fusulinella inflata seems to be idential with Fusulinella deprati Yabe; and of the figures included under the name of Schwagerina princeps var. magnae-sphaerae ${ }^{2)}$, there are some $(\mathbb{P} 1$. XVIII., figs. 3, 4, 7. 8, 9, 10 and Pl. XIX., figs. 9,12) which closely resembles Schwagerinc amedai Deprat and $\mathrm{I}$ see no reason to doubt that they are really identical.

Neoschwagerina parva which M. Colani considered to be an affinity of Neoschwagerina globosa (=Neoschwagerina douvillei) is the same as Neoschwagerina schellwieni (Deprat).

Of the species identified by Colani, the following species.

1) Formerly I described the form having the septa of globosa-type and larger. initial chambex $(0.8 \mathrm{~mm}$. in diameter) by the name Yabeina hayasakal n. sp.

2) On Schwagerina amedai she remarks "Schwagerina amedai Dep., ne donnerait, semblemit-il, pas lieu à des criciques", but, when she diagnoses her new variety Schroagerina princeps var. magnae-sphaerae, she does not make any reference to Schwagerincs amedci. 
listed on the left column are synonyms of the species of the right column.

Colani's determination

Doliotina ce. neoschwagerinoides

Deprat

Neoschwagerina globosa Yabe

Neoschwagerina inouyei Deprat
Revised names

Neoschwagerina (Cancellina) primigena Hayden

Neoschwagerina douvillei

Ozawa

Neoschwagerina globosa Yabe.

\section{Description of the Species.}

\section{Fusulinella (Girtyina) konnoi OzawA}

Pl. X., figs. 1, 2, 3 .

1925. Frusulinella konnoi Y. Ozawa: On the Classification of Fusulinidae. Jour. Coll. Sci. Tokyo Imp. Univ., Vol. XLV., art. 4. P1. IV., figs. $6,7$.

Shell spindle shaped, small. Ratio of length to breadth 2.5:1. Septa and shell-wall covered by deposition layers. Septa intensely folded. Buccal aperture small. Initial chamber small and rate of growth of whorls slow as seen fron the following measurements of a specimen having axial length of $4 \mathrm{~mm}$.

\begin{tabular}{|l|c|}
\hline \multicolumn{1}{|c|}{ Volution } & Rate of growth \\
\hline Initial chamber & $0.1-0.12 \mathrm{~mm}$ \\
1st Volution & 0.26 \\
$2 \mathrm{nd} \quad$, & 0.34 \\
3rd $"$ & 0.51 \\
4th $"$ & 0.77 \\
5th $"$ & 1.07 \\
6th & 1.46 \\
\hline
\end{tabular}


Remarks and Occurrence:-The present specimens belong to Staif and Wedekind's Girtyina. There are none confounded with this species. It occurs associated with indeterminable Fusulina and Staffella, etc. in the Fusulina limestone overlain by the coalbearing sandstone group in Manchuria and Korea. The localities are the Heijo coal-field ${ }^{1)}$ in Korea, Yentai ${ }^{2)}$ and Penhsi-hü ${ }^{3)}$ coalfield in Sheng-sching, Manchuria.

Age: Upper Carboniferous.

\section{Fusulinella praecursor (DEPRAT)}

PI. IX., figs. 5, 6. Pl. X., figs. 4, 5, 6, 7, 8.

1913. Neofusulinella praecursor Deprat: Fusulinidés de Chine et d'Indochine. Mém. Serv. Géol. d'Indochine, Vol. 1I., fas. I. p. 40. P1. VIT., figs. 6-16.

1924. Neofusulinella praecursor Colani; Contribution à l'Étude des Fusulinidés, Mém. Serv. Géol. d'Indochine, Vol. XI., Fas. 1, p. 101. Pl. XVI., figs. 6, 11, 17, 23-48. Pl. XVIT., figs. 1-22.

This species is well illustrated and described by Colani. The following table contains the measurements made on the present specimens.

\begin{tabular}{|l|c|c|}
\hline \multicolumn{1}{|c|}{ Volution } & No. of septa & Pate of growth \\
\hline Initial chamber & $5-7$ & $0.08 \mathrm{~mm}$ \\
Ist Volution & 11 & 0.17 \\
2nd & 12 & 0.31 \\
$3 \mathrm{rd}$ & 14 & 0.41 \\
$4 \mathrm{th}$ & 16 & 0.58 \\
$5 \mathrm{th}$ & 16 & 0.86 \\
$6 \mathrm{th}$ & 18 & 1.24 \\
\hline
\end{tabular}
1) 平䍿炭田
2) 煙台
3) 盛京省本溪湖炭田 
Remarks:-Deprat's description of his species has been considerably amplified by Colani, whose beautiful figures have enabled me to recognize Fusulinella praecursor among my collection of Japanese Fusulinae. The masses of rock specimen are composed almost exclusively of this species.

Locality;-From the Fusulina limestone of Tahara1), at about 18 kilometers west of Nariwa in the Province of Bitchu.

Age: Permian.

Iusulina (Schellwienia) prisca var. parvula ScheLtw. Pl. IX., figs. 2, 3, 4. Pl. X., fig. 9.

1908-09 Fusulina prisca var. parvula H. v. Staff: Monographie der Fusulinen. Paleontographica Vol. 55, p. 184. Pl. XIX., figs. 14. 15.

1912.? Fusulina centralis var. irregularis H. v. Staff: Monographie der Fusulinen. Teil. 3. pp. 178-179. Pl. XVI., figs.7,9. P1. XVII., figs. 5, 7, 10, ? 11.

1924. Fusulina brevicula Schwager, Hayasaka: On the Funna of the Anthracolithic limestone of Omi-mura. p. 15, pl. II., figs. 9, 10, 12, Pl. III., fig. 2.

1925. Fusulina ef. prisca var. parvula Schellwien, Ozawa: Paleontological Studies of the Iimestone of Nagato. p. 39. Pl V., fig. 3.

Shell small, longly fusiform, more or less rounded at ends. The proportion of length to width ranges from 2.8 to 3.2. The largest number of whorls observed is 6 . The rate of growth of the whorls and the number of the septa in each whorl are given in the next page.

Remarks:-According to Schellwien, the chief features by which the present variety can be distinguished from Fusulino prisca are the small dimensions and the slow rate of growth of

1）偘峴國吹屋村田原 


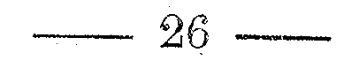

\begin{tabular}{|l|c|c|}
\hline \multicolumn{1}{|c|}{ Volution } & No. of septa & Rate of growth \\
\hline Initial chamber & & $0.15 \mathrm{~mm}$ \\
Ist volution & 11 & 0.26 \\
2nd & 13 & 0.39 \\
$3 \mathrm{rd}$ & 15 & 0.60 \\
$4 \mathrm{th}$ & 19 & 0.99 \\
5 th & 22 & 1.60 \\
6 th & 25 & 2.10 \\
\hline
\end{tabular}

the whorls. V. Staff compared a Nortin American Fusulina centralis var. irregularis with Fusulina regulas is Schellwien, but there is in many respects a close relationship between the former and Fusulina prisca var. parvula. The only points in which Fusulina centralis var. irregularis shows any difference from Fusulina prisca var. parvula are the slender shell-wall and more or less pointed ends of the shell. But in examining a large numbex of specimens which I identified with Fusulina prišca var. parvula I am struck by the fact that the above differences are not so important as to separate the species.

It occurs very abundantly in the Fusulina limestone of Omimura ${ }^{1)}$, Prov. of Echigo.

Age: Upper Carboniferous.

\section{Verbeekina alicige (DEPIAT)}

Pl. VIII., fig. 1.

1912. Doliolina aliciae Deprat: Fusulinidés de Chine et d'Indochine Mém. Serv. Géol. d'Indochine Vol. I, fas. 3. p. 43, Pl. V., figs. $11-14$.

A glance at Plate VIII., fig. I will show that the present specimens correspond exactly with Deprat's type of the species though they are not the orientated sections.

1) 䢕後圆班海村 
This species associated with Frusuina ef. ambigua Deprat and Mizaia velebitana Schubert is found in the Fusulina limestone collected at Shirai, twelve miles east-east-north of Takayama in the province of Hida. ${ }^{1}$ )

Age: Permian.

\section{Explanation of Plates. \\ Plate IX.}

Kig. 1. Verbeekina alicice (Deprat). Loc. Shirai, Prov. Hida. Higs. 2, 3, 4. Fusu?ina (Schellwienia) prisca var. parvula Shellwien. Loc. Omi-mura, Prov. Echigo.

Figs. 5, 6. Fusulinella praecursor (Deprat).

Loc. Tahara, Prov. Bitchu.

\section{Plate $X$.}

Figs. 1, 2, 3. Fusulinella konnoi Ozawa.

Loc. Pen-hsi-hu eoal-field in Manchuria.

Figs. 4, 5, 6, 7, 8. Fusulinella procursor (Deprat).

Loc. Tahara, Prov. Bitchu.

Tig. 9. Fusulina (Schellwienia) prisca var. parvula Schellwien.

Loc. Omi mura, Prov. Echigo.

1) 飛㗪國白韭 